\title{
Nephroblastoma with lymphatic metastasis in an Angus calf: scientific communication
}

\author{
Nefroblastoma com metástase linfática em um bezerro Angus: \\ comunicação científica
}

\author{
Matheus Viezzer Bianchi ${ }^{1 *}$; Guilherme Konradt ${ }^{1}$; Ronaldo Viana Leite-Filho'; \\ Débora Zaro²; Thayane Santana Mikhailenko²; David Driemeier ${ }^{3}$
}

\begin{abstract}
Nephroblastoma is a congenital renal neoplasm composed of metanephric blastema and stromal cells. A one-year-old male Angus calf presented with diarrhea, nasal discharge, cough and weight loss. Serum levels of creatinine and urea were increased, with reduction in the level of albumin. After eight days, clinical condition got worse and the calf died. On necropsy, the cranial pole of the left kidney presented a firm whitish mass $(30 \times 21 \times 14 \mathrm{~cm})$. Multifocal to coalescing firm whitish nodules were observed on the serosa of the large intestine, in the mesentery and in the adventitia of the urinary bladder. All lung lobes contained multifocal to coalescing firm whitish elevated nodules $(0.5$ to $1 \mathrm{~cm}$ of diameter). Histologically, renal mass consisted of neoplastic proliferation of embryonal epithelial and mesenchymal cells, intermixed with large amounts of blastema cells. The nodules on large intestine, mesentery, urinary bladder and lungs were composed mainly of blastema cells and mild amount of mesenchymal cells. Blastema cells were also observed within lymphatic vessels in lung parenchyma. Embryonal epithelial, mesenchymal and blastema cells showed, respectively, positive immunostain for cytokeratin, vimentin and S100. Based on pathological and immunohistochemical findings, the tumor was diagnosed as nephroblastoma in a calf with metastasis through lymphatic vessels to lungs, large intestine, mesentery and urinary bladder.
\end{abstract}

Key words: Cattle. Congenital. Neoplasm. Nephroblastoma.

\section{Resumo}

O nefroblastoma é uma neoplasia renal congênita composta por um blastema metanéfrico e células estromais. Um bezerro Angus, macho, de um ano de idade apresentou diarreia, descarga nasal, tosse e perda de peso. Os níveis de creatinina e ureia estavam aumentados, com albumina diminuída. Após oito dias, a condição clínica piorou e o bezerro veio a óbito. Na necropsia, o polo cranial do rim esquerdo apresentou uma massa brancacenta firme $(30$ × 21 x $14 \mathrm{~cm})$. Nódulos brancacentos firmes multifocais a coalescentes foram visualizados na serosa do intestino grosso, mesentério e adventícia da bexiga. Nos pulmões nódulos elevados brancacentos firmes $(0.5$ a $1 \mathrm{~cm}$ de diâmetro) multifocais a coalescentes foram observados. Histologicamente, a massa no rim consistia em proliferação neoplásica de células embrionais epiteliais e mesenquimais, entremeadas a grande quantidade de células blastemais. Os nódulos no intestino grosso, mesentério, bexiga e pulmões eram compostos principalmente por células

\footnotetext{
${ }^{1}$ Discentes, Universidade Federal do Rio Grande do Sul, UFRGS, Porto Alegre, RS, Brasil. E-mail: matheusviezzerb@hotmail. com; guikonradt@yahoo.com.br; vianaleite@hotmail.com

${ }^{2}$ Médicas Veterinárias, Hospital de Clínicas Veterinárias, Faculdade de Veterinária, Universidade Federal do Rio Grande do Sul, UFRGS, Porto Alegre, RS, Brasil. E-mail: deborazaro@hotmail.com; thayanesantana90@gmail.com

3 Prof., Universidade Federal do Rio Grande do Sul, UFRGS, Porto Alegre, RS, Brasil. E-mail: davetpat@ufrgs.br

* Author for correspondence.
} 
blastemais e discreta quantidade de células mesenquimais. As células blastemais foram também observadas no interior de vasos linfáticos no parênquima pulmonar. As células embrionais epiteliais, mesenquimais e blastemais apresentaram, respectivamente, imunomarcação positiva para citoqueratina, vimentina e S100. Baseado nos achados patológicos e imuno-histoquímicos este caso foi diagnosticado como um nefroblastoma em um bezerro com metástases através de vasos linfáticos aos pulmões, intestino grosso, mesentério e bexiga.

Palavras-chave: Bovino. Congênita. Nefroblastoma. Neoplasia.

Nephroblastomas, also known as Wilm's tumors or embryonal nephromas, are congenital renal neoplasms composed of metanephric blastema and stromal cells (MEUTEN, 2002), and are usually described as a mixture of three cell populations: epithelial, mesenchymal, and blastema cells (MAXIE; NEWMAN, 2007).

Nephroblastoma is the most common primary renal neoplasm of swine and chicken (MEUTEN, 2002), and more recently has also been reported in cattle, mostly in fetus, in which it was associated with dystocia in cows and buffalo during calving (DEVI et al., 2011; MADHESWARAN et al., 2014); cases have also been described a few in adult cattle (YAMAMOTO et al., 2006; SCAGLIONE et al., 2012), and there is no apparent breed predisposition. This tumor has been occasionally reported in horses (JARDINE; NESBIT, 1996), sheep (HEADLEY et al., 2006) and dogs (MONTINARO et al., 2013).

Grossly, nephroblastoma presents as a single, polar and unilateral mass, occupying a large proportion of the affected kidney and may be large enough to compress abdominal viscera (MEUTEN, 2002). The histological features include a disorganized mixture of embryonal epithelial and mesenchymal tissues, with embryonic glomeruli, irregular and branching tubules, encompassed by variable amounts of loose mesenchymal stroma and foci of proliferating blast-like cells, with scant cytoplasm (MEUTEN, 2002).

This report describes the clinical, gross, microscopic, and immunohistochemical findings of a nephroblastoma with lymphatic metastasis to the large intestine, mesentery, urinary bladder and lungs in a one-year-old male Angus calf.
A one-year-old male Angus calf was referred to the Hospital de Clínicas Veterinárias da Universidade Federal do Rio Grande do Sul (Porto Alegre, RS) with a two-month history of severe diarrhea, moderate nasal discharge, cough and weight loss. Physical examination revealed mild bradycardia (44 bpm; RV: 60-80 bpm) and mild tachypnea (44 breaths/min; RV: $10-30$ breaths/ min). The complete blood count (CBC) showed normocytic hypochromic anemia (hemoglobin 4.8 g/dL, RV: 8 -15 g/dL; hematocrit 17\%, RV: $24-$ 46\%; MCV 51.20 fL, 40 - 60; MCHC 28.23\%, 30 - 36), with the presence of metarubricytes $(3 / 100)$ leukocytosis $(23.900 / \mu \mathrm{L}$; RV: $4.000-12,000 / \mu \mathrm{L})$ and neutrophilia $(8.000 / \mu \mathrm{L}$; RV: $600-4.000 / \mu \mathrm{L})$. Biochemistry parameters revealed increased in the activity of creatinine $(5.18 \mathrm{mg} / \mathrm{dL}$; reference value [RV]: $0.9-2.0 \mathrm{mg} / \mathrm{dL})$ and urea $(191 \mathrm{mg} / \mathrm{dL} ; \mathrm{RV}$ : $20-30 \mathrm{mg} / \mathrm{dL})$, with decreased albumin $(21 \mathrm{~g} / \mathrm{dL}$; RV: $30.3-35.5 \mathrm{~g} / \mathrm{dL}$ ). Differential diagnosis for persistent infection associated with bovine viral diarrhea virus was performed through RT-PCR for pestivirus, with a negative result. After eight days of admission, clinical condition worsened to sternal recumbence, severe tachycardia, and tachypnea, resulting in spontaneous death.

At necropsy, the abdominal and thoracic cavities contained 3 and 4 liters, respectively, of a yellowish serous fluid (specific gravity $<1.020 \mathrm{mg} / \mathrm{dL}$; poor in cells and proteins; ascites and hydrothorax). The cranial pole of the left kidney was expanded by a firm whitish mass $(30 \times 21 \times 14 \mathrm{~cm})$, with irregular surface, replacing approximately $40 \%$ of the parenchyma (Figure 1.A); the right kidney was not affected. The serosa of the large intestine, the mesentery and the adventitia layer of the urinary 
bladder also presented multifocal to coalescing firm whitish nodules measuring 1 to $1.5 \mathrm{~cm}$ of diameter. - All pulmonary lobes contained multifocal to coalescing firm, whitish elevated nodules measuring 0.5 to $1 \mathrm{~cm}$ of diameter, that extended to the parenchyma on the sectioned surface (Figure 1.B). Fragments of right and left kidneys, lungs, small and large intestines, mesentery, urinary bladder, liver, heart, lymph nodes, spleen, brain and spinal cord were collected, fixed in $10 \%$ neutral buffered formalin and routinely processed for histopathological examination. Sections from the left kidney and lung with the mass were submitted to immunohistochemical evaluation for cytokeratin
(1:80; AE1/AE3, DakoCytomation, Carpinteria, CA, USA), vimentin (1:200; Zymed, Carlsbad, CA, USA), S100 (1:200; DakoCytomation, Carpinteria, CA, USA), and smooth muscle actin (1:100, Dakocytomation, Carpinteria, CA, USA). Antigenic retrieval in all procedures was obtained by boiling the sections in citrate buffer ( $\mathrm{pH}$ 6.0) for 3 minutes at $125^{\circ} \mathrm{C}$. Sections were incubated overnight at 8 ${ }^{\circ} \mathrm{C}$. Amplification signal was achieved by using LSAB-HRP Universal kit (Dakocytomation, Carpinteria, CA, USA). Reaction was revealed with 3,3'-diaminobenzidine (DAB, Sigma, St Louis, MO, USA). Slides were counterstained with Mayer's hematoxylin.

Figure 1. Nephroblastoma with lymphatic metastasis in an Angus calf. A. Left kidney. The cranial pole is expanded by a focally extensive firm whitish mass with irregular surface, measuring $30 \times 21 \times 14 \mathrm{~cm}$. B. Lungs. Multifocal to coalescing whitish firm raised nodules measuring 0,5 to $1 \mathrm{~cm}$ of diameter on the visceral pleura, that extended to the parenchyma on cut surface (inset).
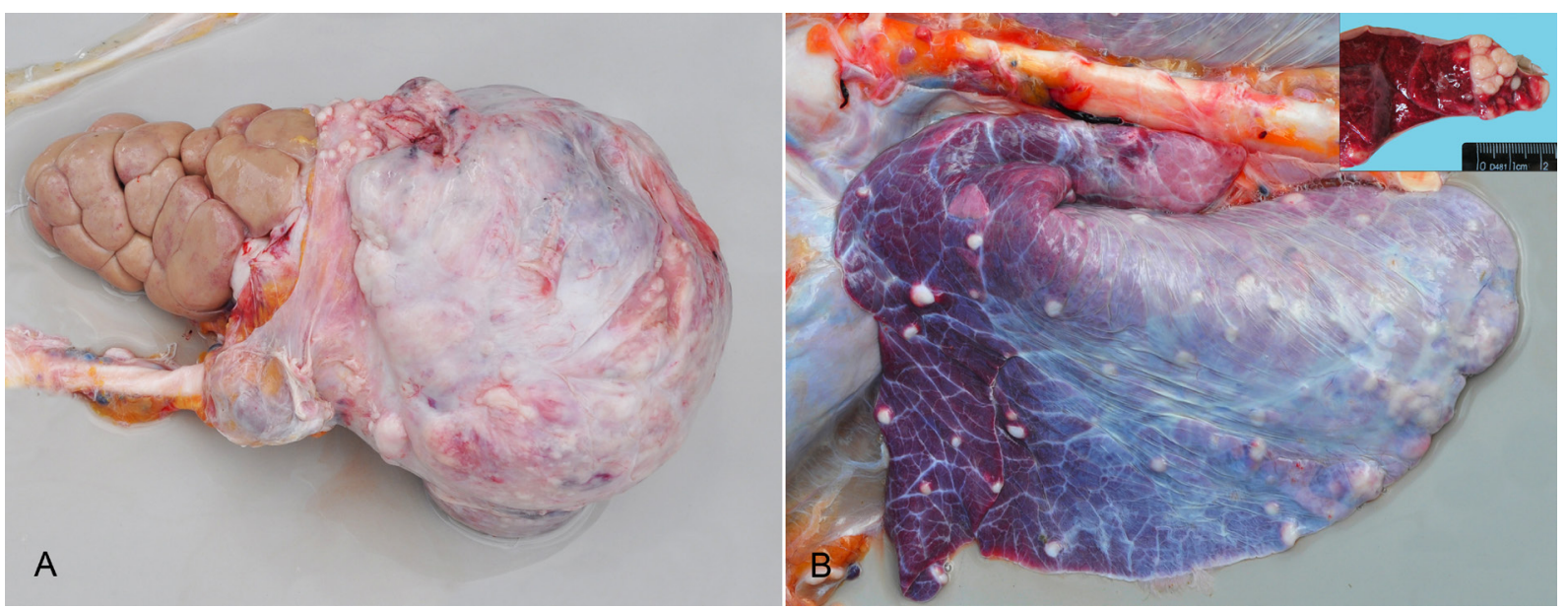

By histopathology, the renal mass consisted of a densely cellular proliferation partially encapsulated and infiltrative of embryonal epithelial and mesenchymal neoplastic cells, intermixed with large amounts of blastema cells (Figure 2.A). Embryonal epithelial cells were organized in irregular branching tubules and in immature glomeruli without capillaries. These cells were cuboidal, with welldemarcated cytoplasm, rounded nuclei with finely stippled chromatin, and rare mitosis. Mesenchymal cells were fusiform, arranged in bundles, with large undefined cytoplasm, frequently myxomatous. The blastema cells were arranged in closely packed nests and were round with scanty cytoplasm, hyperchromatic nuclei, occasionally with evident nucleoli, with two atypical mitotic figures per highpower field at 400x magnification. The neoplasm also presented multifocal areas of hemorrhage and thrombosis. In the adjacent left kidney parenchyma there were moderate multifocal necrosis of tubular 
cells and multiple intratubular hyaline cylinders (proteinuria) in the cortex. The nodules observed at the large intestine, mesentery, urinary bladder and lungs revealed multifocal areas composed mainly of blastema cells and mild amount of mesenchymal cells. Blastema cells were also observed within lymphatic vessels in the pulmonary parenchyma (Figure 2.A inset). Adjacent alveolar spaces to lung nodules were severely atelectatic, and moderate edema was also noted.

Figure 2. Nephroblastoma with lymphatic metastasis in an Angus calf. A. Left kidney. Neoplastic proliferation of embryonal epithelial and mesenchymal cells, intermixed with large amounts of blastema cells. Embryonal epithelial cells are organized in irregular branching tubules and immature glomeruli. Mesenchymal cells were fusiform and arranged in bundles. HE, 10x. Inset. Lung. Blastema cells were observed within lymphatic vessels in the pulmonary parenchyma. HE, 40x. B. Embryonal epithelial cells showed marked positive stain; while embryonal mesenchymal and blastema cells were negative. Immunohistochemistry anti-cytokeratin, 10x. C. Embryonal mesenchymal cells showed marked positive stain; while embryonal epithelial and blastema cells were negative. Immunohistochemistry antivimentin, 10x. D. Blastema cells showed marked positive stain; embryonal epithelial cells moderate; and embryonal mesenchymal cells mild. Immunohistochemistry anti-S100, 40x.

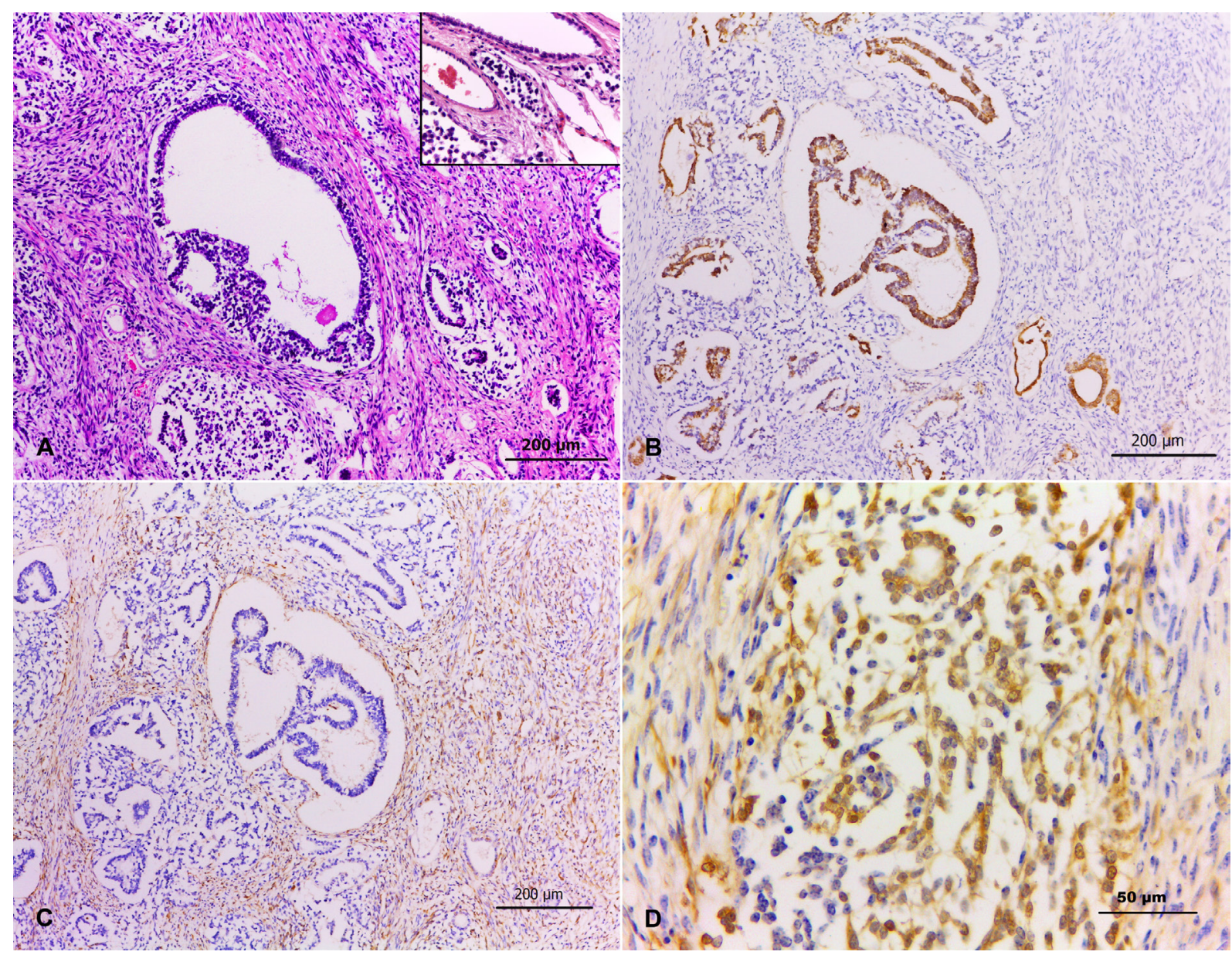

By immunohistochemistry, embryonal epithelial cells showed marked positive stain for cytokeratin (Figure 2.B), moderate positive for S100, and negative for vimentin and smooth muscle actin. Embryonal mesenchymal cells were marked positive for vimentin (Figure 2.C) and smooth 
muscle actin, mild for S100, and negative for cytokeratin. Blastema cells were marked positive for S100 (Figure 2.D), while negative for cytokeratin, vimentin and smooth muscle actin.

Histogenesis of nephroblastoma is controversial, with two hypothesis postulated: according to Jardine and Nesbit (1996), there is an apparent progressive development from the nests of cell-dense blastema to primitive tubules, which appear to mirror the process of renal embryogenesis; however, according to Vujanić et al. (2002), rests of tissue with embryonic potentialities that persist in postnatal kidneys may suffer a neoplastic transformation. This seems to be more likely in this case, considering the age of the calf and because congenital nephroblastoma in fetus is often associated with dystocia (DEVI et al., 2011; MADHESWARAN et al., 2014).

Clinically, $\mathrm{CBC}$ showed normocytic hypochromic anemia, that most likely occurred due to chronic hemorrhage in the neoplasm. This may happen with trauma, abnormal hemostasis, certain forms of parasitism, ulceration and neoplasia (FRY; MCGAVIN, 2012), as in the present case. A finding that may accompany regeneration is the presence of nucleated erythroid cells (FRY; MCGAVIN, 2012), such as the present finding of metarubricytes in the $\mathrm{CBC}$, which allowed us to classify this as a regenerative process. Biochemistry parameters revealed elevated blood levels of creatinine and urea, which indicate a reduced glomerular filtration and a failure to excrete metabolic wastes (MAXIE; NEWMAN, 2007). These probably occurred due to the necrosis of the left kidney tubular cells adjacent to the neoplasm, while the decreased albumin was most likely a consequence of proteinuria which was highlighted by the intratubular hyaline cylinders.

In ruminants, the mesenchymal elements of nephroblastomas tend to be as equally developed as the epithelial components (MEUTEN, 2002). Tubular and glomerular differentiation may indicate a less aggressive growth (SCAGLIONE et al., 2012), as was seen partially in the present case in the renal tumor, which showed moderate primitive tubular and glomerular structures intermixed with large amounts of blastema cells and mesenchymal stroma. However, anaplastic differentiation is usually indicative of an increased likelihood of metastasis (SCAGLIONE et al., 2012), as herein identified by the multiple metastatic nodules present in the lungs, large intestine, mesentery, and urinary bladder, which consisted predominantly of undifferentiated blastema cells with scanty mesenchymal stroma. The blastema cells were also observed within lymphatic vessels in lungs, confirming the malignancy of the neoplasm. In a case reported with pulmonary metastasis, mesenchymal stroma was scanty and consisted of thin bundles, which penetrated the neoplastic epithelial tissue (SCAGLIONE et al., 2012). Yamamoto et al. (2006) also found that epithelial elements were rare in metastatic nodules, which were composed mainly of blastema and stromal elements, as observed during this investigation.

The stromal element is composed of spindle cells revealing positive immunostaining for vimentin, smooth muscle actin and desmin; epithelial component is marked positive for cytokeratin; while blastema cells are mildly positive for cytokeratin (YAMAMOTO et al., 2006) and vimentin (SCAGLIONE et al., 2012). Instead, in this report we found in this case that the blastema cells were negative for cytokeratin and vimentin, which is in agreement with Castiglioni et al. (2013), and marked positive for S100. The mesenchymal cells are marked positive for vimentin and smooth muscle actin, which is in agreement with Yamamoto et al. (2006), which may demonstrate that these cells are differentiating into smooth muscle tissue (CASTIGLIONI et al., 2013).

According to Meuten (2002), if the host is a species other than swine, metastasis is expected and likely sites include regional sublumbar and mesenteric lymph nodes, as well as the lungs and liver. Transcelomic metastasis to the lungs was described by Yamamoto et al. (2006) in a 
bull. However, herein we described based on histopathology that metastasis most likely occurred through lymphatic vessels than transcelomical, because blastema neoplastic cells were observed within lymphatic vessels on the lungs. Prognosis was poor considering the size of the mass and the complexities of surgical removal (JARDINE; NESBIT, 1996), and also the multifocal distribution on lungs, causing respiratory distress which was clinically noted as severe tachycardia and tachypnea.

Based on the gross, microscopic and immunohistochemical findings observed, this case was diagnosed as nephroblastoma in an Angus calf with metastasis to lungs, large intestine, mesentery and urinary bladder. Still, metastasis on this case was most likely through lymphatic vessels, differing from what has been already described on literature (YAMAMOTO et al., 2006). IHC showed that blastema cells were immunoreactive to S100.

\section{References}

CASTIGLIONI, V.; DE MAGLIE, M.; QUELITI, R.; RUSTIGHI, A.; DEL SAL, G.; RADAELLI, E. Immunohistochemical characterization of a renal nephroblastoma in a trp53-mutant and prolyl isomerase 1-deficient mouse. Journal of Toxicologic Pathology, Tokyo, v. 26, n. 4, p. 423-427, 2013.

DEVI, V. R.; VEERAIAH, G.; YEDUKONDALU, K.; BEGUM, S. K.; ANNAPURNA, P.; SUNITHA, P.; DEVI, M. A. Congenital nephroblastoma in a buffalo calf. Brazilian Journal of Veterinary Pathology, Botucatu, v. 4, n. 3, p. 225-226, 2011.

FRY, M. M.; MCGAVIN, M. D. Bone marrow, blood cells, and the lymphatic system. In: ZACHARY, J. F.; MCGAVIN, M. D. Pathologic basis of veterinary disease. $5^{\text {th }}$ ed. Missouri: Elsevier, 2012. p. 698-770.
HEADLEY, S. A.; SAUT, J. P. E.; MAIORKA, P. C. Nephroblastoma in an adult sheep. The Veterinary Record, London, v. 159, n. 25, p. 850-852, 2006.

JARDINE, J. E.; NESBIT, J. W. Triphasic nephroblastoma in a horse. Journal of Comparative Pathology, Edinburgh, v. 114, n. 2, p. 193-198, 1996.

MADHESWARAN, R.; PALANISAMY, M.; MANOKARAN, S.; SIVASEELAN, S.; BALASUBRANIAM, G. A.; VIJAYAKUMAR, G.; SELVARAJU, M.; NAPOLEAN, R. E. Congenital nephroblastoma in a Holstein-Friesian fetus - case report. Veterinarski Arhiv, Zagreb, v. 84, n. 2, p. 199-204, 2014.

MAXIE, M. G.; NEWMAN, S. J. Urinary system. In: MAXIE, M. G. Jubb, Kennedy, and Palmer's pathology of domestic animals. $5^{\text {th }}$ ed. Philadelphia: Saunders Elsevier, 2007. v. 2, p. 501-502.

MEUTEN, D. J. Tumors of the urinary system. In: . Tumors in domestic animals. $4^{\text {th }}$ ed. Iowa State: Blackwell Publishing, 2002. p. 518-519.

MONTINARO, V.; BOSTON, S. E.; STEVENS, B. Renal nephroblastoma in a 3-month-old golden retriever. Canadian Veterinary Journal, Ottawa, v. 54, n. 7, p. $683-$ 686, 2013.

SCAGLIONE,F.E.;RICCARDO,P.;MICHELANGELO, B.; MARIO, A.; LAURA, C.; ELIGIO, F.; FEDERICO, V.; ENRICO, B. Nephroblastoma with pulmonary metastasis in 33 month old neutered piedmontese male cattle. Pakistan Veterinary Journal, Faisalabad, v. 32, n. 4, p. 627-630, 2012.

VUJANIĆ, G. M.; SANDSTED, B.; HARMS, D.; KELSEY, A.; LEUSCHNER, I.; KRAKER, J. de. Revised international society of pediatric oncology (SIOP) working classification of renal tumor in childhood. Medical and Pedriatic Oncology, Malden, v. 38, n. 2, p. 79-82, 2002.

YAMAMOTO, Y.; YAMADA, M.; NAKAMURA, K.; TAKAHASHI, Y.; MIYAMOTO, T. Nephroblastoma with transcoelomic metastasis in a Japanese Black bull. Journal of Veterinary Medical Science, Tokyo, v. 68, n. 8, p. 891-893, 2006. 